\title{
Glycerol ether biomarkers and their carbon isotopic compositions in a cold seep carbonate chimney from the Shenhu area, northern South China Sea
}

\author{
GE Lu ${ }^{1}$, JIANG ShaoYong ${ }^{1 *}$, YANG Tao ${ }^{1}$, YANG JingHong ${ }^{1}$, WU NengYou ${ }^{2}$, \\ ZHANG GuangXue ${ }^{2} \&$ LIU Jian ${ }^{2}$ \\ ${ }^{1}$ State Key Laboratory for Mineral Deposits Research and Center for Marine Geochemistry Research, Department of Earth Sciences, Nanjing \\ University, Nanjing 210093, China; \\ ${ }^{2}$ Guangzhou Marine Geological Survey, Guangzhou 510760, China
}

Received August 19, 2010; accepted January 4, 2011

\begin{abstract}
At modern cold seeps, the anaerobic oxidation of methane (AOM) is the dominant pathway for methane consumption in marine sediments. AOM, which is mediated by a consortium of methane oxidizing archaea and sulfate reducing bacteria, is proposed to be responsible for authigenic carbonate formation. A methane-derived carbonate chimney was collected from the Shenhu area, northern South China Sea. The membrane lipids and their very low carbon isotopic compositions ( $-115 \%$ o to $-104 \%$ ) in the Shenhu chimney suggest the presence of an AOM process. Three specific archaeal and bacterial biomarkers were detected, including Ar, DAGE 1f, and monocyclic MDGD. Their strongly depleted $\delta^{13} \mathrm{C}$ values $(-115 \%$ o to $-104 \%$ ), which are lower than those of the normal marine lipids in sediments, reveal biogenic methane as their origin. The carbonate deposits exhibiting a chimney structure indicate that a vigorous methane-rich fluid expulsion may have occurred at the seafloor. We propose that the decomposition of gas hydrates at depth is the likely cause of seepage and cold seep carbonate formation in the Shenhu area.
\end{abstract}

cold seep carbonates, anaerobic oxidation of methane, carbon isotopic composition, glycerol ethers biomarkers

Citation: Ge L, Jiang S Y, Yang T, et al. Glycerol ether biomarkers and their carbon isotopic compositions in a cold seep carbonate chimney from the Shenhu area, northern South China Sea. Chinese Sci Bull, 2011, 56: 1700-1707, doi: 10.1007/s11434-011-4486-z

Methane-derived carbonate precipitation is a striking phenomenon at hydrocarbon seeps on active and passive continental margins worldwide [1-4]. The seepage of methane rich fluids on passive margins generally originates from hydrate water released during gas hydrate destabilization and/or is associated with rapidly accumulating sediments $[1,5,6]$. These methane-rich fluids are generally derived from underlying sediments that migrate along deep-reaching faults or conduit upwards through the sediment column. When rising methane reaches the upper parts of the sediment, it is oxidized, coupled with sulfate reduction in an anaerobic environment at the base of the sulfate reduction zone. This is known as the anaerobic oxidation of methane

\footnotetext{
*Corresponding author (email: shyjiang@ nju.edu.cn)
}

(AOM) [7-9]. AOM is mediated by methane oxidizing archaea (MOA) in conjunction with sulfate reducing bacteria (SRB). In the case of an AOM process, sulfate and methane are consumed in a 1:1 molar ratio, producing sulfide and bicarbonate $\left(\mathrm{HCO}_{3}^{-}\right)$(see eq. (1)), leading to an increase in alkalinity that favors carbonate precipitation (see eq. (2)) $[2,10,11]$.

$$
\begin{gathered}
\mathrm{CH}_{4}+\mathrm{SO}_{4}^{2-} \rightarrow \mathrm{HS}^{-}+\mathrm{HCO}_{3}^{-}+\mathrm{H}_{2} \mathrm{O} \\
\mathrm{Ca}^{2+}+\mathrm{HCO}_{3}^{-} \rightarrow \mathrm{CaCO}_{3}+\mathrm{H}^{+}
\end{gathered}
$$

The molecular fingerprints of the chemosynthesis based microbial communities at methane seeps tend to be extremely well preserved in authigenic carbonates [12].

Lipid biomarkers are constituents of the cytoplasmic 
membrane surrounding each cell, which allow the identification of dominant microbes and, if combined with a compound specific stable carbon isotope analysis, their carbon fixation pathways [13-15]. The identification of AOM communities was achieved using independent molecular techniques, i.e. 16S rDNA clone libraries and/or fluorescence in situ hybridization, as well as lipid biomarker analyses [15]. In contrast to marine dissolved inorganic carbon, which typically has a $\delta^{13} \mathrm{C}$ value close to 0 [16], $\delta^{13} \mathrm{C}$ signatures of AOM derived lipids are extremely ${ }^{13} \mathrm{C}$ depleted with $\delta^{13} \mathrm{C}$ values lower than $-50 \%$ [15], even down to $-130 \%$ [17]. Therefore, typical anaerobic-related lipid biomarkers and their compound-specific stable carbon isotopes can be used to trace AOM communities in modern and ancient environments [12,15].

In general, bacterial membranes consist of phospholipids built from fatty acids which are ester bonded to a glycerol backbone. These fatty acids may contain double bonds, methyl branches or ring structures. In contrast, archaeal biomarkers contain branched isoprenoidal alcohols and glycerol tetraethers $[15,18,19]$.

Since the early 1990s, gas hydrate exploration has been carried out in northern South China Sea, and gas hydrate samples were first extracted from the Shenhu area in 2007 [20]. Recent studies in the South China Sea have mainly been focused on geophysical surveys and pore water and gas geochemistry studies [21-26], but little is known about the AOM processes and their lipid biomarkers. The ${ }^{13} \mathrm{C}$-depleted AOM biomarkers are abundant in sediments and cold seep carbonates from the Dongsha islands, northern South China Sea, which implies the operation of AOM processes in this region [17,27]. In 2004, the research vessel Haiyangsihao trawled carbonate chimneys in the Shenhu area. In this paper, we report on the lipid biomarkers and their carbon isotopic composition in these Shenhu carbonate chimneys. We examined the relationship between these lipids and the methane oxidizing archaea and SRB, which revealed their carbon source and genetic link with gas hydrates.

\section{Geologic setting and samples}

The South China Sea is one of the largest marginal seas in the west Pacific under the influence of the Eurasian, Pacific and India-Australian plates. The oceanic basement is dotted with buried volcanic structures and several have developed deep-reaching faults that act as methane-rich fluid pathways $[6,28,29]$. Methane-derived carbonates have been found in all three gas hydrates prospecting the target areas in the northern continental slope of the South China Sea, e.g. Xisha trough, Shenhu area, and Dongsha islands [29-36]. Their depleted $\delta^{13} \mathrm{C}$ values are consistent with that of the cold seep carbonates in the Gulf of Mexico, where gas hydrates are abundant, indicating that these carbonates are formed in cold seep systems. Consequently, the northern continental slope of the South China Sea, which contains faulted terraces and basins that provide significant sources of oil and natural gas, is considered to be a favorable location for gas hydrate formation and conservation.

Our study area, Shenhu, is located between the Xisha trough and the Dongsha islands, adjacent to several large oil and gas fields, with a water depth between 300 and $3500 \mathrm{~m}$ [29] (Figure 1). Thick sediments are abundant in organic matter $(0.44 \%-1.75 \%)$ and contain an unusually high concentration of methane [29,37]. This organic matter is considered to be the source of early microbial-generated methane, found throughout the sediment sequences [38]. Gas hydrate containing sediment samples were firstly drilled out in this area at 153-225 m below the seafloor in 2007 [20].

The chimney studied in this paper is about $11 \mathrm{~cm}$ long and $6 \mathrm{~cm}$ in diameter (Figure 2). Obvious conduits occur in the center of the chimney, with layered structures likely due to multiple stages of seepage. A range of different fossils were found on the surface of the chimney. The chimneys are composed of variable levels of Fe rich dolomite, aragonite, high $\mathrm{Mg}$ calcite, low $\mathrm{Mg}$ calcite, clay minerals and terrigenous quartz and feldspar, and exhibited a highly depleted $\delta^{13} \mathrm{C}$ value and a heavy $\delta^{18} \mathrm{O}$ value [29].

\section{Methods}

\subsection{Chemical treatment}

Chemical treatment of the sample involves preparation, decalcification, saponification and extraction of the lipid biomarkers [39]. The carbonate chimney was crushed into small pieces and cleaned by repeated washing with $10 \%$ $\mathrm{HCl}$ and acetone. To avoid transesterification reactions at low $\mathrm{pH}$, doubly distilled water was added to the sample and $10 \% \mathrm{HCl}$ was slowly poured on the sample to dissolve the carbonate until $\sim 80 \%$ of the sample had been dissolved. Any remaining sample fragments were removed and the residue was centrifuged. After washing with water, the samples were saponified in $6 \% \mathrm{KOH}$ in methanol [40]. The supernatants were decanted and the residues were extracted repeatedly by ultrasonication in dichloromethane/methanol $(3: 1 \mathrm{v} / \mathrm{v})$ until the solvent became colorless. The combined supernatants were partitioned in dichloromethane and water treated with $10 \% \mathrm{HCl}$ to $\mathrm{pH} 2$. The organic extracts were separated into four fractions using Supelco LC-NH2 glass cartridges with a sequence of solvents of increasing polarity: (1) hydrocarbons, $4 \mathrm{~mL} n$-hexane; (2) ketones/esters, $6 \mathrm{~mL}$ n-hexane/DCM 3:1; (3) alcohols, $7 \mathrm{~mL}$ DCM/acetone 9:1; and (4) fatty acids, $8 \mathrm{~mL} 2 \%$ formic acid in DCM. The alcohols were analyzed as their trimethylsilylesters (TMS-derivatives) and the fatty acids were analyzed as methylesters.

\subsection{GC-MS biomarkers compounds analyses}

All fractions were examined by gas chromatography-mass 


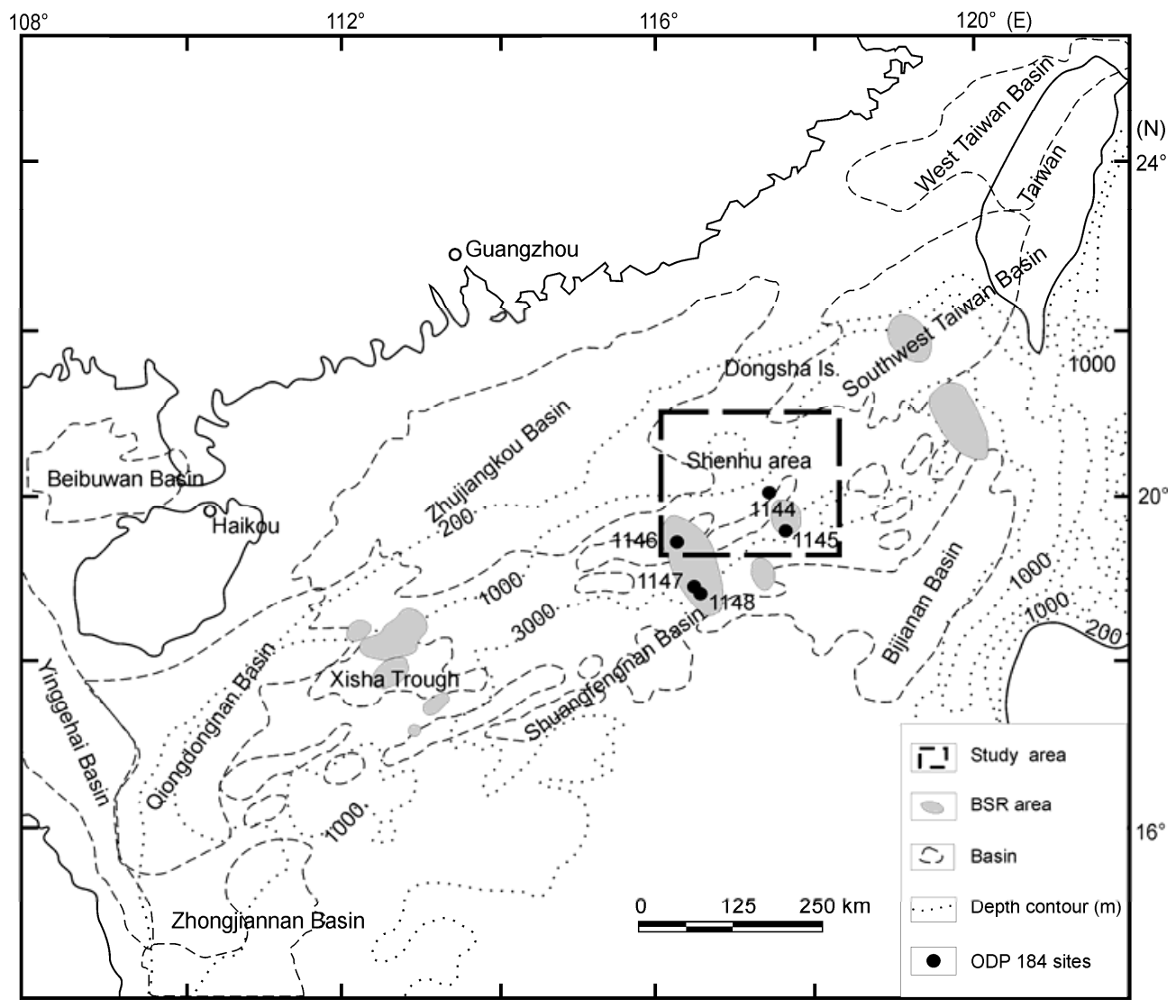

Figure 1 Location of the Shenhu study area in the northern part of the South China Sea BSR area is the target region of gas hydrate exploration.
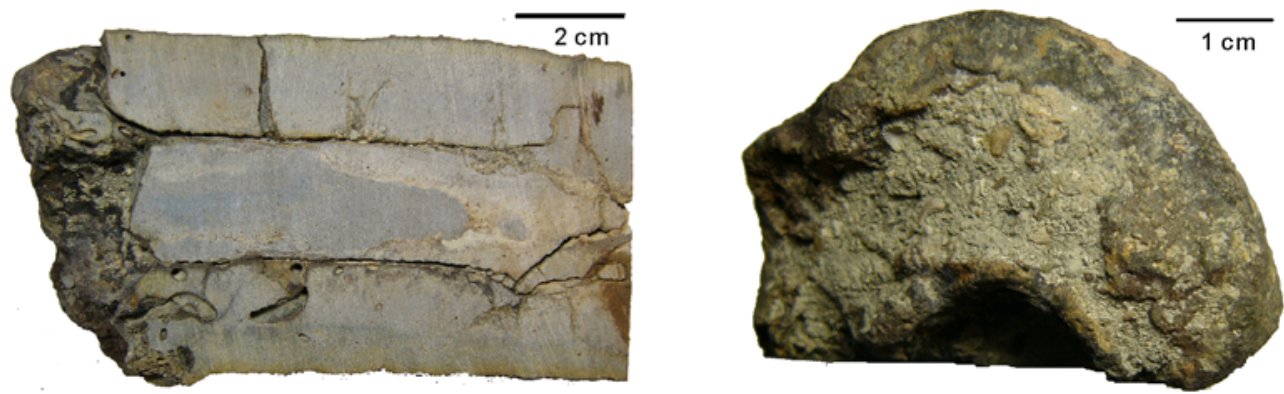

Figure 2 Typical morphologies of the Shenhu carbonate chimney.

spectrometry using a Thermo Electron Trace GC-MS equipped with a $30 \mathrm{~m}$ RTX-5M5 fused silica capillary column (0.32 mm i.d., $0.25 \mu \mathrm{m}$ film thickness), with He as the carrier gas. The GC temperature program used for all fractions was as follows: $60^{\circ} \mathrm{C}, 1 \mathrm{~min}$ isothermal; from 60 to $150^{\circ} \mathrm{C}$ at $10^{\circ} \mathrm{C} / \mathrm{min}$; from 150 to $320 \mathrm{C}$ at $4^{\circ} \mathrm{C} / \mathrm{min}, 22 \mathrm{~min}$ isothermal. For analyzing fractions (3) and (4), an extended temperature program was applied: $60^{\circ} \mathrm{C}, 1 \mathrm{~min}$ isothermal; from 60 to $150^{\circ} \mathrm{C}$ at $15^{\circ} \mathrm{C} / \mathrm{min}$; from 150 to $330^{\circ} \mathrm{C}$ at $4^{\circ} \mathrm{C} /$ $\mathrm{min}, 60 \mathrm{~min}$ isothermal. The identification of the individual compounds was based on GC retention times and mass spectra upon comparison with published reference data
$[15,17]$

\subsection{Carbon isotope analyses}

The compound specific carbon isotopic composition was analyzed by a Hewlett Packard 5890 GC via a Thermo Electron Trace GC combustion unit interfaced to a Finnigan MAT 252 mass spectrometer. The GC conditions were in accordance with those described above. Carbon isotopes are given as $\delta^{13} \mathrm{C}$ in \%o abundance relative to the V-PDB standard. The standard deviation of the analytical error is lower than $0.4 \%$. All measurements were carried out at MARUM, 
Bremen University.

\section{Results and discussion}

\subsection{Identification of AOM lipid biomarkers}

Niemann and Elvert reported the diagnostic lipid biomarker and stable carbon isotope signatures of microbial communities mediating the AOM with sulfate [15]. AOM lipid biomarkers consist of archaeal biomarkers and bacterial biomarkers. Archaeal biomarkers include (1) the $\mathrm{C}_{20}$ and $\mathrm{C}_{25}$, irregular tail-to-tail linked, isoprenoidal hydrocarbons, e.g. 2,6,11,15-tetramethylhexadecane (crocetane) and 2,6,10,15, 19-pentamethyleicosane (PMI) and their unsaturated homologues; and (2) the isoprenoidal glycerol ethers, such as archaeol (Ar) and sn2-/sn3-/di-hydroxyarchaeol [15]. In AOM environments, bacterial biomarkers co-occurring with ${ }^{13} \mathrm{C}$-depleted archaeal lipids are evident by their highly depleted carbon isotope composition compared with the source carbon. Therefore, the significant ${ }^{13} \mathrm{C}$ depletion indicates the methane carbon incorporation into microbial biomass [41-44]. Typical bacterial biomarkers are fatty acids and alkyl glycerol esters. Alkyl glycerol esters derived from SRB involved in AOM include the non-isoprenoidal monoalkyl glycerol ethers and non-isoprenoidal mono and dialkyl glycerol ethers (DAGEs) [15]. The presence of these lipid biomarkers is regarded as good evidence for AOM.

Due to the low content of organic matter in the Shenhu carbonate chimney, no obvious hydrocarbons or fatty acids were found in these samples. Three lipids belonging to alcohols associated with AOM are recognized in the samples (Figure 3): Ar, DAGE 1f, and monocyclic macrocyclic diphytanyl glycerol diether (monocyclic MDGD). These lipids bear their own characteristics and significance.

Ar is bis-O-phytanyl glycerol ether has a molecular weight is 652 (Figure 4). It is analyzed as its TMS-derivatives which has a molecular weight of 724. The fragment ions are $m / z=\mathrm{M}-\mathrm{C}_{n} \mathrm{H}_{2 n+1} \mathrm{OH}, m / z=\mathrm{M}-\mathrm{C}_{n} \mathrm{H}_{2 n+1} \mathrm{OCH}_{3}$, and $m / z$ $=\mathrm{C}_{n} \mathrm{H}_{2 n+1} \mathrm{O}+\mathrm{Si}\left(\mathrm{CH}_{3}\right)_{3}-\mathrm{H}$ [45]. Ar is one of the most com- mon core ether lipids in archaea and is especially prominent in thermophiles, halophiles, and methanogens [46]. Ar is universally present in anaerobic sediments at cold seeps associated with gas hydrates, modern methane seep systems, and methane-rich mud volcanoes [8,46-48]. In AOM environments, the incorporation of methane derived from carbon into these lipids is indicated by their very low $\delta^{13} \mathrm{C}$ values. Significant amounts of ${ }^{13} \mathrm{C}$ depleted $\mathrm{Ar}$ were reported from all methane oxidizing archaea habitat studies, with $\delta^{13} \mathrm{C}$ values varying between $-120 \%$ and $-61 \%$ [15]. Strongly ${ }^{13} \mathrm{C}$ depleted $\mathrm{Ar}$ is found in the Shenhu carbonate chimney, indicating AOM processes in this region. Microbial communities utilize the carbon from methane, leading to archaeal biomarkers having very low $\delta^{13} \mathrm{C}$ values.

GC-MS analyses of DAGE if revealed mass spectral fragment ions consistent with a non-isoprenoidal dialkyl glycerol diether structure, with an anteiso $\mathrm{C}_{15}$ alkyl chain at both the $s n-1$ and $s n-2$ positions (Figure 4) [49]. The molecular weight is 584. DAGE $1 \mathrm{f}$ is characterized by the $m / z, 130$ radical ion in its mass spectra. In addition, the spectra consists of the signals $\mathrm{m} / \mathrm{z} 133,342$, and 356. It is still unclear whether DAGE $1 \mathrm{f}$ is directly produced by the syntrophic SRB or by yet unidentified source organisms. It seems likely that DAGE 1f derives from bacteria, especially SRB rather than archaea $[15,49,50]$. DAGEs have, to date, only been observed in deeply branching thermophilic sulfatereducing bacterium, such as Thermodesulfobacterium commune and Thermodesulfobacterium hveragerdense [51, 52]. These thermophilic SRB contain diethers with $C_{16}-C_{18}$ anteiso, iso and $n$-alkyl chains. The most abundant diether comprised two $\mathrm{C}_{17}$ anteiso alkyl chains, analogous to those in DAGE 1f [49]. DAGE 1f was found in cold seep carbonate crusts from a mud volcano in the Mediterranean, with $\delta^{13} \mathrm{C}$ values from $-99.6 \%$ o to $-71.2 \%$, which is lower than that of the normal marine biomarkers [53]. This suggests that the source organisms utilize carbon, at least partially, derived from ${ }^{13} \mathrm{C}$-depleted methane. However, DAGE 1f is strongly enriched in ${ }^{13} \mathrm{C}$ compared to Ar derived from methane-oxidizing archaea, suggesting, the source organisms

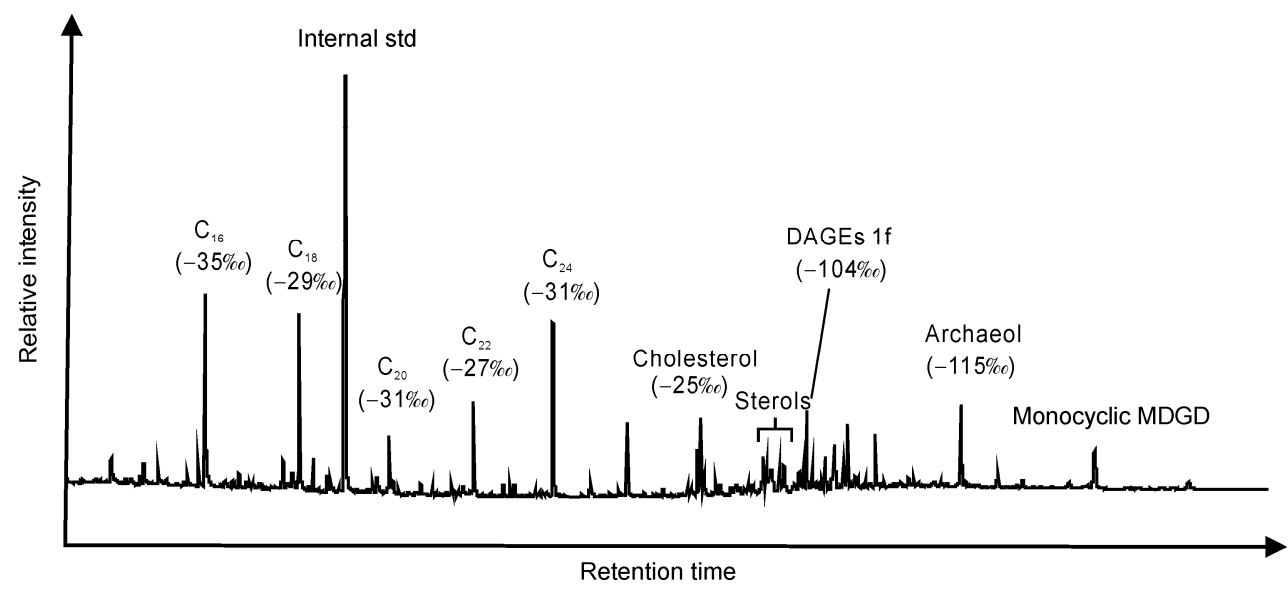

Figure 3 TIC gas chromatogram of alcohols from the Shenhu carbonate chimney. 

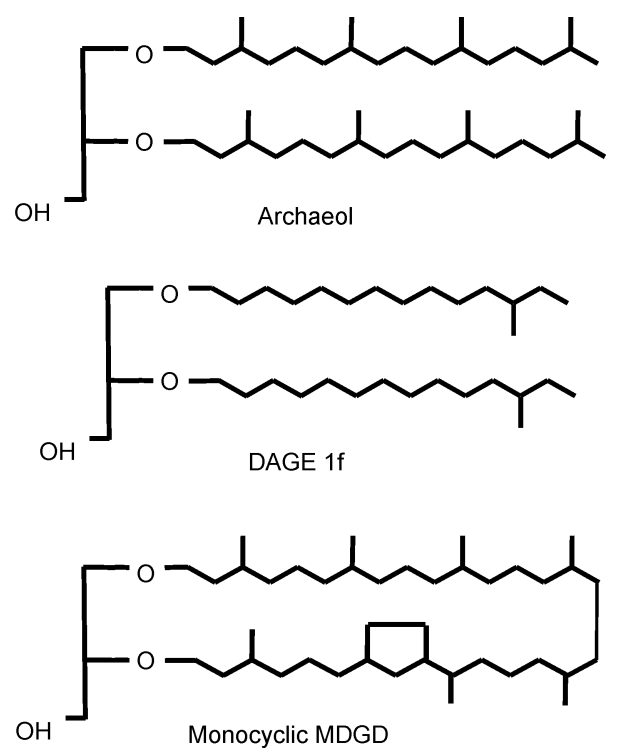

Figure 4 Structures of archaeol, DAGE 1f, and monocyclic MDGD.

did not directly assimilate methane [49]. One possibility is that heterotrophs utilize sulfate or some other oxidant available in the crust precipitation environment. An alternative explanation is that the bacteria utilize dissolved inorganic carbon (DIC), and a large portion of DIC derives from oxidized methane. In the process of carbonate precipitation, DIC concentrations are inferred to be significantly higher than in ambient seawater and this should serve as a viable carbon source [49]. DAGEs are detected in the Shenhu carbonate chimney, but because of the low concentrations, only DAGE $1 \mathrm{f}$ is identified.

In addition to the two well-known archaeal and bacterial lipids discussed above, a novel group of archaeal isoprenoids was also observed in the Shenhu carbonate chimney. These were MDGDs bearing a pentacyclic ring (monocyclic MDGD) (Figure 4). The mass spectra show intense fragment ions at $\mathrm{m} / \mathrm{z} 145$, which arise from the loss of the entire biphytantl moiety and a hydroxyl group, $\mathrm{C}_{3} \mathrm{H}_{4} \mathrm{O}_{2} \mathrm{Si}\left(\mathrm{CH}_{3}\right)_{3}$. Other characterized fragment ions were $\mathrm{m} / \mathrm{z} 43,57,90,103$, 130,131, and 132 [54]. Archaeal core membrane lipids contain a cyclopentane ring and a cyclohexane ring $[18,55]$. The presence and location of the cyclopentane ring in the biphytanyl chains is revealed by the fragment ion at $\mathrm{m} / \mathrm{z}, 165$ (Figure 4). Because archaeal anaerobic methanotrophy results in highly ${ }^{13} \mathrm{C}$-depleted lipids, monocyclic MDGD is derived from methanotrophic archaea [54]. This type of archaea biosynthesize structurally related GDGTs containing biphytane chains with one or two cyclopentane rings [48,56,57]. The thermophilic methanogen Methanococcus jannaschii is the only archaeon known to contain the macrocyclic diether as its core membrane lipid [58]. However, cyclopentane containing GDGTs are well known in thermophilic crenarchaeota, thermophilic euryarchaeota, as well as marine mesophilic crenarchaeota and mesophilic euryarchaeota capable of AOM [54]. Until now, this compo- nent has only been reported in a methane-derived carbonate crust from the Sorokin trough, northeastern Black Sea and the Miocene Marmorito limestone in northern Italy [12,54]. They all have significantly depleted carbon isotopic compositions (-104\%o and $-105 \%$ ), suggesting they are derived from methanotrophic archaea acting within AOM consortia, which subsequently induce authigenic carbonate formation [54]. The presence of monocyclic MDGD shows that it is most likely related to an AOM process. It is, however, still unknown whether methanotrophic archaea or other unknown seep endemic archaea synthesize this group of compounds, or if they represent diagenetic products putatively derived from GDGTs [12].

\subsection{Carbon source of glycerol ethers biomarkers}

The sources of carbon for cold seep carbonates include (1) methane from biogenic methane $\left(\delta^{13} \mathrm{C}<-65 \%\right.$ ) to thermogenic sources $\left(\delta^{13} \mathrm{C}\right.$ : $-30 \%$ o to $-50 \%$ ), (2) sedimentary organic carbon $\left(\delta^{13} \mathrm{C}=-20 \%\right.$ o), and (3) marine carbonate (0) [59]. The significantly depleted ${ }^{13} \mathrm{C}$ isotopic compositions $(-40.18 \%$ o to $-38.69 \%$ o $)$ of the Shenhu carbonate chimney suggest that the carbon source is from methane [29]. Since the methane vertical flux is low in the Shenhu area, the methane which forms the gas hydrates is most likely to be biogenic in origin [38].

AOM lipid biomarkers in the Shenhu carbonate chimney show strongly depleted $\delta^{13} \mathrm{C}$ values $(-115 \%$ o to $-104 \%$, Figure 3), which are significantly lower than that of normal lipids in marine sediments $\left(\delta^{13} \mathrm{C}=-25 \%\right.$ ). The carbon isotopic compositions are similar to those from typical cold seeps worldwide [15], suggesting that microbial communities utilize the carbon from methane and that cold seepage is active in the Shenhu area. The $\delta^{13} \mathrm{C}$ value of $\mathrm{Ar}$ is $-115 \%$, which is within the range of methane-derived carbonates worldwide [15] ( $-116 \%$ o to $-88 \%$ ), implicating methaneoxidizing archaea as their origin. The $\delta^{13} \mathrm{C}$ value of DAGE 1f is $-104 \%$ o, considerably lower than the values for cold seep carbonates in mud volcanoes in the Mediterranean $(-99.6 \%$ o to $-71.2 \%$ o). This low value is consistent with Ar, suggesting that these components have the same carbon source. We propose that DAGE $1 f$ in the Shenhu carbonate chimney is produced by SRB. Because methane is dominant in Shenhu marine sediments [38] (96.10\%-99.82\%), the carbon isotopic compositions of these AOM biomarkers confirm the carbon source to be biogenic methane, which is in agreement with inference report by $\mathrm{Wu}$ et al. [38].

Compared with the Dongsha area of the South China Sea (Figure 5), AOM biomarkers in cold seep carbonates from the Shenhu area have unique characteristics. Despite only alcohols being detected in Shenhu chimney, the lipids contained both archaeal biomarkers and bacterial biomarkers. Hydrocarbons (crocetane, PMI and squalane) and isoprenoidal glycerol ethers (Ar and hydroxyarchaeol) found in 


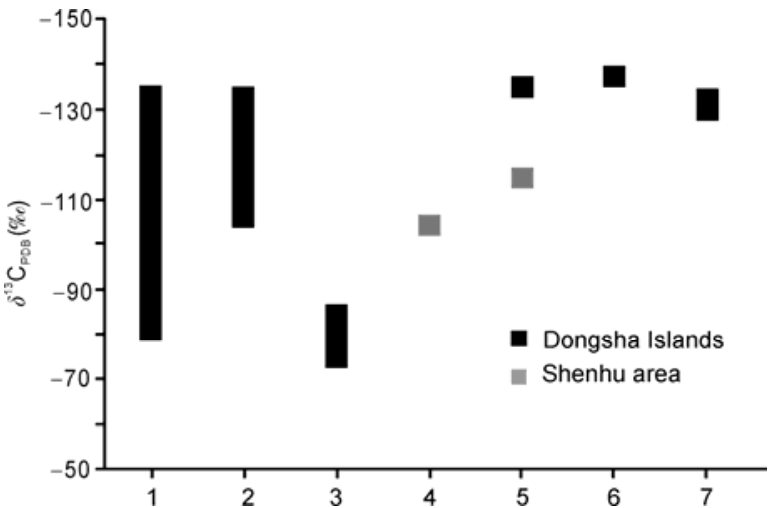

Figure 5 Carbon isotope composition of AOM biomarkers in cold seep carbonates from the Shenhu and Dongsha areas (data for Dongsha samples are from [17,27]). 1, Crocetane; 2, PMI; 3, squalane; 4, DAGE; 5, archaeol; 6 , hydroxyarchaeol; 7 , biphytanic diacids.

Dongsha carbonates are typical archaeal biomarkers [17,27]. In addition, ${ }^{13} \mathrm{C}$-depleted biphytanic diacids are considered to be derived from euryarchaeota metabolizing methane [27]. AOM processes were detected in both the Shenhu and Dongsha areas, but the microbial communities involved in each AOM are different. Methane oxidizing archaea and SRB were active in the Shenhu seep sites and only SRB were found in the Dongsha area. However, the $\delta^{13} \mathrm{C}$ values in the Dongsha biomarkers range widely from $-137 \%$ o to $-74.2 \%$. This suggests that these lipids are not exclusively derived from anaerobic methanotrophs, and may originate from other archaea, probably methanogens [27]. The $\delta^{13} \mathrm{C}$ values of the Shenhu AOM biomarkers are all similar and lower than $-100 \%$, suggesting that these biomarkers are derived from anaerobic methanotrophs and SRB.

\subsection{Sources of methane-rich fluids}

The ${ }^{13} \mathrm{C}$-depleted AOM biomarkers are abundant in cold seep carbonates from the Dongsha area of the northern South China Sea, implying that the carbonates are formed in AOM reactions and that vigorous methane-rich fluid expulsions have occurred at the seafloor $[17,27]$. In this study, AOM biomarkers (Ar, DAGE 1f, and monocyclic MDGD) and their carbon isotopic compositions $(-115 \%$ o to $-104 \%$ o) have confirmed the presence of AOM processes in the Shenhu carbonate chimney.

The seepage of methane-rich fluids on passive margins is generally driven by the compaction of rapidly accumulating sediments and/or gas hydrate dissolution [1,6]. The abundant organic matter in the Shenhu sediments is therefore beneficial for methane formation. Moreover, the thick sediments in this area are easily dehydrated by any compaction, leading to the expulsion of fluids [29]. The source of methane from which the gas hydrates in the Shenhu area are formed is biogenic methane [38]. The carbonate deposits present in the chimney structure indicate that the fluid expulsion was somewhat vigorous, or at least highly channel- ized [59]. The carbonate chimneys are at the sediment surface, but because they incorporate terrigenous components, it is proposed that they were initially formed within the unconsolidated sediments and later became exposed by erosion [60]. The presence of AOM biomarkers and their carbon isotopic composition implicate a biogenic methane source, consistent with the gas hydrates. In this case, we propose that the decomposition of gas hydrates is the major reason for seepage in the Shenhu area. When rising methane from gas hydrate dissolution is anaerobically oxidized by methane oxidizing archaea and SRB, it gives rise to the precipitation of carbonate chimneys.

\section{Conclusions}

Three specific AOM biomarkers were found in the cold seep carbonate chimney from the Shenhu area: Ar, DAGE 1f, and monocyclic MDGD. This suggests the occurrence of archaeal and bacterial biomarkers, and the existence of an AOM process. Their strongly depleted $\delta^{13} \mathrm{C}$ values $(-115 \%$ o to $-104 \%$ o) reveal biogenic methane to be the source. The carbonate deposits displaying a chimney structure indicate that a vigorous methane-rich fluid expulsion has occurred at the seafloor and the decomposition of gas hydrates is likely to be the major reason of seepage in the Shenhu area.

This manuscript benefited from thoughtful suggestions by N. Gary Hemming, and three anonymous reviewers. This work was supported by the National Natural Science Foundation of China (40773029, 40903002 and 40772073) and the National Basic Research Program of China (2009CB219506).

1 Bohrmann G, Greinert J, Suess E, et al. Authigenic carbonates from the Cascadia subduction zone and their relation to gas hydrate stability. Geology, 1998, 26: 647-650

2 Peckmann J, Reimer A, Luth U, et al. Methane-derived carbonates and authigenic pyrite from the northwestern Black Sea. Mar Geol, 2001, 177: 129-150

3 Campbell K A, Farmer J D, Marais D D. Ancient hydrocarbon seeps from the Mesozoic convergent margin of California: Carbonate geochemistry, fluids, and palaeoenvironments. Geofluids, 2002, 2: 63-94

4 Peckmann J, Thiel V. Carbon cycling at ancient methane-seeps. Chem Geol, 2004, 205: 443-467

5 Ding W W, Wang Y M, Chen H L, et al. Deformation characters and its tectonic evolution of the Southwest Taiwan Basin (in Chinese). J Zhejiang Univ, 2004, 31: 216-220

6 Han X Q, Suess E, Huang Y Y, et al. Jiulong methane reef: Microbial mediation of seep carbonates in the South China Sea. Mar Geol, 2008, 249: $243-256$

7 Reeburgh W S. Methane consumption in Carian Trench waters and sediments. Earth Planet Sci Lett, 1976, 28: 337-344

8 Hinrichs K U, Hayes J M, Sylva S P, et al. Methane-consuming archaebacteria in marine sediments. Nature, 1999, 398: 802-805

9 Aloisi G, Pierre C, Rouchy J M, et al. Methane-related authigenic carbonates of eastern Mediterranean Sea mud volcanoes and their possible relation to gas hydrate destabilization. Earth Planet Sci Lett, 2000, 184: 321-338

10 Ritger S, Carson B, Suess E. Methane-derived authigenic carbonates formed by subduction-induced pore-water expulsion along the Oregon/Washington margin. Geol Soc Am Bull, 1987, 98: 147-156 
11 Paull C K, Chanton J P, Neumann A C, et al. Indicators of methane-derived carbonates and chemosynthetic organic carbon deposits: Examples from the Florida Escarpment. Palaios, 1992, 7: 361-375

12 Birgel D, Peckmann J. Aerobic methanotrophy at ancient marine methane seeps: A synthesis. Org Geochem, 2008, 39: 1659-1667

13 Boschker H T S, Nold S C, Wellsbury P, et al. Direct linking of microbial populations to specific biogeochemical processes by ${ }^{13} \mathrm{C}$ labelling of biomarkers. Nature, 1998, 392: 801-805

14 Brocks J J, Pearson A. Building the biomarker tree of life. Rev Mineral Geochem, 2005, 59: 233-258

15 Niemann H, Elvert M. Diagnostic lipid biomarker and stable carbon isotope signatures of microbial communities mediating the anaerobic oxidation of methane with sulphate. Org Geochem, 2008, 39: 1668-1677

16 Kroopnick P M. The distribution of $\delta^{13} \mathrm{C}$ of $\Sigma \mathrm{CO}_{2}$ in the world oceans. Deep-Sea Res Part A-Oceano Res Papers, 1985, 32: 57-84

$17 \mathrm{Yu} \mathrm{X} \mathrm{G,} \mathrm{Han} \mathrm{X} \mathrm{Q,} \mathrm{Li} \mathrm{H} \mathrm{L,} \mathrm{et} \mathrm{al.} \mathrm{Biomarkers} \mathrm{and} \mathrm{carbon} \mathrm{isotope}$ composition of anaerobic oxidation of methane in sediments and carbonates of northeastern part of Dongsha, South China Sea (in Chinese). Acta Oceanol Sin, 2008, 30: 77-84

18 De Rosa M, Gambacorta A. The lipids of archaebacteria. Prog Lipid Res, 1988, 27: 153-175

19 Koga Y, Nishihara M, Morii H, et al. Ether polar lipids of methanogenic bacteria: Structures, comparative aspects, and biosyntheses. Microbiol Rev, 1993, 57: 164-182

20 Zhang H, Yang S, Wu N, et al. China's first gas hydrate expedition successful. Fire in the Ice: Methane Hydrate Newsletter, National Energy Technology Laboratory, US Depart Ener, 2007, Spring/ Summer issue, 1

21 Yao B C. The forming condition and distribution characteristics of the gas hydrate in the South China Sea (in Chinese). Offshore Oil, 2007, 27: $1-10$

22 Wang H B, Zhang G X, Yang M Z, et al. Structural circumstance of gas hydrate deposition in the continent margin, the South China Sea (in Chinese). Mar Geol Quat Geol, 2003, 23: 81-86

23 Sun C Y, Niu B H, Wang H Y, et al. An intergrated study method for exploration of gas hydrate reservoirs in marine areas (in Chinese). Chin J Geophy, 2004, 47: 1076-1085

24 Jiang S Y, Yang T, Xue Z C, et al. Chlorine and sulfate concentrations in pore waters from marine sediments in the north margin of the South China Sea and their implications for gas hydrate exploration (in Chinese). Geoscience, 2005, 19: 45-54

$25 \mathrm{Fu} \mathrm{S} \mathrm{Y.} \mathrm{The} \mathrm{geochemical} \mathrm{characteristics} \mathrm{of} \mathrm{free} \mathrm{gases} \mathrm{and} \mathrm{pore} \mathrm{water}$ from core sediments in Dongsha area, South China Sea (in Chinese). South China Sea Geol Res, 2005, 1: 29-37

26 Yang T, Jiang S Y, Yang J H, et al. Dissolved inorganic carbon (DIC) and its carbon isotopic composition in sediment pore waters from the Shenhu area, northern South China Sea. J Oceanol, 2008, 64: 303-310

27 Birgel D, Elvert M, Han X Q, et al. ${ }^{13} \mathrm{C}$-depleted biphytanic diacids as tracers of past anaerobic oxidation of methane. Org Geochem, 2008, 39: $152-156$

28 He J Q, Zhou Z Y, Li J B, et al. Research on Continental Margin Structure, Northern South China Sea: Statues and Prospects (in Chinese). Beijing: China Ocean Press, 2002. 65-74

29 Lu H F, Chen F, Liu J, et al. Characteristics of authigenic carbonate chimneys in Shenhu area, northern South China Sea: Recorders of hydrocarbon-enriched fluid activity (in Chinese). Geol Rev, 2006, 52: 352-357

30 Chen D F, Huang Y Y, Yuan X L, et al. Seep carbonates and preserved methane oxidizing archaea and sulfate reducing bacteria fossils suggest recent gas venting on the seafloor in the Northeastern South China Sea. Mar Petrol Geol, 2005, 22: 613-621

31 Chen D F, Huang Y Y, Feng D, et al. Seep carbonate and preserved bacteria fossils in the northern of the South China Sea and their geological implications (in Chinese). Bull Mineral Petrol Geochem, 2005, 24: $185-189$

$32 \mathrm{Lu} \mathrm{H} \mathrm{F,} \mathrm{Liu} \mathrm{J,} \mathrm{Chen} \mathrm{F,} \mathrm{et} \mathrm{al.} \mathrm{Mineralogy} \mathrm{and} \mathrm{stable} \mathrm{isotopic} \mathrm{composi-}$ tion of authigenic carbonates in bottom sediments in the offshore area of southwest Taiwan, South China Sea: Evidence for gas hydrates occurence (in Chinese). Earth Sci Front, 2005, 12: 268-276

33 Chen Z, Huang Q Y, Yan W, et al. Authigenic carbonates as evidence for seeping fluids in Xisha trough of South China Sea (in Chinese). J Tropical Oceanol, 2007, 26: 26-33

34 Chen Z, Yan W, Chen M H, et al. Discovery of seep carbonate nodules as new evidence for gas venting on the northern continental slope of South China Sea. Chinese Sci Bull, 2006, 51: 1065-1072

35 Chen Z, Yang H P, Huang Q Y, et al. Diagenetic environment and implication of cold seep carbonate precipitations from the southwestern Dongsha area, South China Sea (in Chinese). Geoscience, 2008, 22: $382-389$

36 Su X, Chen F, Lu H F, et al. Micro-texture of methane seep carbonates from the northern South China Sea in correlation with fluid flow (in Chinese). Geoscience, 2008, 22: 376-381

37 Lu J A, Yang S X, Wu N Y, et al. Well logging evaluation of gas hydrates in Shenhu area, South China Sea (in Chinese). Geoscience, 2008, 22: 447-451

38 Wu N Y, Zhang H Q, Yang S X, et al. Preliminary discussion on natural gas hydrate reservoir system of Shenhu area, north slope of South China Sea (in Chinese). Nat Gas Indus, 2007, 27: 1-7

39 Birgel D, Thiel V, Hinrichs K U, et al. Lipid biomarker patterns of methane-seep microbialites from the Mesozoic convergent margin of Califonia. Org Geochem, 2006, 37: 1289-1302

40 Elvert M, Niemann H. Occurrence of unusual steroids and hopanoids derived from aerobic methanotrophs at an active marine mud volcano. Org Geochem, 2008, 39: 167-177

41 Hinrichs K U, Summons R E, Orphan V, et al. Molecular and isotopic analysis of anaerobic methane-oxidizing communities in marine sediments. Org Geochem, 2000, 31: 1685-1701

42 Michaelis W, Seifert R, Nauhaus K, et al. Microbial reefs in the Black Sea fueled anaerobic oxidation of methane. Science, 2002, 297: 1013-1015

43 Elvert M, Boetius A, Knittel K, et al. Characterization of specific membrane fatty acids as chemotaxonomic markers for sulfatereducing bacteria involved in anaerobic oxidation of methane. Geomicrobio J, 2003, 20: 402-419

44 Blumenberg M, Seifert R, Reitner J, et al. Membrane lipid patterns typify distinct anaerobic methanotrophic consortia. Proc Nat Acad Sci USA, 2004, 101: 11111-11116

45 Teixidor P, Grimalt J O, Pueyo J J, et al. Isopranylglycerol diethers in non-alkaline evaporitic environments. Geochim Gosmochim Acta, 1993, 57: 4479-4489

46 Koga Y, Morii H, Akagawa-Matsushita M, et al. Correlation of polar lipid composition with $16 \mathrm{~S}$ rRNA phylogeny in methanogens. Further analysis of lipid component parts. Biosci Biotech Biochem, 1998, 62: $230-236$

47 Boetius A, Ravenschlag K, Schubert C, et al. A marine microbial consortium apparently mediating anaerobic oxidation of methane. Nature, 2000, 407: 623-626

48 Pancost R D, Hopmans E C, Sinninghe Damste J S, et al. Archaeal lipids in Mediterranean cold seeps: Molecular proxies for anaerobic methane oxidation. Geochim Gosmochim Acta, 2001, 65: 1611-1627

49 Pancost R D, Bouloubassi I, Aloisi G, et al. Three series of nonisoprenoidal dialkyl glycerol diethers in cold-seep carbonate crusts. Org Geochem, 2001, 32: 695-707

50 Elvert M, Hopmans E C, Treude T, et al. Spatial variations of methanotrophic consortia at cold methane seeps: implications from a highresolution molecular and isotopic approach. Geobiology, 2005, 3: 195-209

51 Langworthy T A, Holzer G, Zeikus J G, et al. Iso- and anteisobranched glycerol diethers of the thermophilic anaerobe Thermodesulfotobacterium commune. Syst Appl Microbiol, 1983, 4: 1-17

52 Sturt H F, Summons R E, Smith K, et al. Intact polar membrane lipids in prokaryotes and sediments deciphered by high-performance liquid chromatography/electrospray ionization multistage mass spectrometry-new biomarkers for biogeochemistry and microbial ecology. Rapid Commun Mass Spectro, 2004, 18: 617-628

53 Hayes J M. Factors controlling ${ }^{13} \mathrm{C}$ contents of sedimentary organic compounds: Principles and evidence. Mar Geol, 1993, 1: 111-125 
54 Stadnitskaia A, Baas M, Ivanov M K, et al. Novel archaeal macrocyclic diether core membrane lipids in a methane-derived carbonate crust from a mud volcano in the Sorokin Trough, NE Black Sea. Archaea, 2003, 1: 165-173

55 Sinninghe Damsté J S, Rijpstra W I C, Hopmans E C, et al. Distribution of membrane lipids of planktonic crenarchaeota in the Arabian Sea. Appl Environ Microbiol, 2002, 68: 2997-3002

56 Aloisi G, Bouloubassi S K, Heijs R D, et al. $\mathrm{CH}_{4}$-consuming microorganisms and the formation of carbonate crusts at cold seeps. Earth Planet Sci Lett, 2002, 203: 195-203

57 Wakeham S G, Lewis C M, Hopmans E C, et al. Archaea mediate anaerobic oxidation of methane in deep euxinic waters of the Black
Sea. Geochim Gosmochim Acta, 2003, 67: 1359-1374

58 Comit P B, Gagosian R B, Pang H, et al. Structural elucidation of a unique macrocyclic membrane lipid from a new, extremely thermophilic, deep-sea hydrothermal Vent archaebacterium, Methanococcus jannaschii. J Biol Chem, 1984, 259: 15234-15241

59 Stakes D S, Orange D, Paduan J B, et al. Cold-seeps and authigenic carbonate formation in Monterey Bay, California. Mar Geol, 1999, 159: 93-109

60 Peckmann J, Theil V, Michaelis W, et al. Cold seep deposits of Beauvoisin (Oxfordian; Southeastern France) and Marmorito (Miocene; northern Italy): Microbially induced authigenic carbonates. Inter J Earth Sci, 1999, 88: 60-75

Open Access This article is distributed under the terms of the Creative Commons Attribution License which permits any use, distribution, and reproduction in any medium, provided the original author(s) and source are credited. 